are questions as close to the core of morality as to conservation. To attack them at all demands the attention of the finest ecological, sociological and political minds we can muster. The answer is urgent, as each passing decade brings us either further on the down grade or nearer the asymptote. We know not which.

It has been relatively easy to find support for conservation on the American continent, where our man-to-space ratio has been low, hunger has not been an alternative where an acre was allocated to quality of living rather than to food for survival, and where the economic advantages were obvious. The pressures will change as the alternatives gain more immediacy.

Central to conservation on this continent is the gradual change in the legal view of the rights of the individual in relation to the long-term benefits to society. In this context certain recent interpretations of the Supreme Court of the United States of America have the greatest significance. That the individual as a member of a society retains only those liberties specifically allocated to him by the society is an interpretation with broad impact in the natural sense. There still remains in many quarters, however, the narrow interpretation that only consumptive use is really use and should take priority in competitions. There is the demand also that even the aesthetic qualities of our lives should be justified in dollar values when alternative uses of land are an issue. Conservation lives in both our worlds, the economic and the aesthetic; tho contribution of the ideology is equally to both, but the standards of comparison are probably invalid.

It is the unique revelation of man that he is not only consciously sensitive to his own environment, but also relates himself to much larger and more complex processes in which he plays a part. His image of the world then becomes an important element in the processes of the world itself.

A central element in our vision of the kind of world we would inhabit is the ideology of conservation. Within it we find values that we will defend and ideas that we seek to propagate. Man has come full circle from the unwilling participant in the processes of survival to become the only ereature whose vision influences those processes. Conservation and other ideology have played so important a part in human affairs and hold so much for man's future.

Even in those unfortunate areas of our own land and others, where avarice and ignorance still triumph, the achievements and ideals of conservation stand as a constant reminder of what could be. Self-consciousness once awakened can no longer be escaped.

\title{
OBITUARY
}

\section{Academician Eugene N. Pavlovsky}

THE death of Eugene Nikanorovitch Pavlovsky on May 27, 1965, in his eighty-second year, deprived Soviet science of one of its most eminent representatives, who dominated the scene of medical zoology in his country for more than half a century and whose outstanding contributions in the field of biology and parasitology found recognition throughout the world.

E. N. Pavlovsky was born on March 5, 1884, in the town of Birjutch, Voronezh Province. After receiving his secondary education at the Borisoglebsk Gymnasium, where he gained a gold medal on matriculation in 1903 , he was admitted to the Military Medieal Academy of St. Petersburg. Though primarily intended for the training of army doctors, the Academy was-and still is- one of the greatest medical schools in Russia, where young Pavlovsky studied under some of the most renowned medical scientists, including I. P. Pavlov, the physiologist, A. A. Maximov, the histologist, and N. A. Cholodkovsky, the zoologist.

Pavlovsky showed an early interest in zoology, and while still a student he started the research work in the laboratory of Prof. Cholodkovsky on the anatomy of lice and on the poison glands of arthropods and fishes, for which the Academy awarded him a gold medal. On graduating with distinction in 1909 , Pavlovsky was appointed assistant to his teacher, N. A. Cholodkovsky, and in 1913 he took the M.D. degree with a thesis on the structure of poison glands in arthropods, and was elected Privat-docent. The first period of Pavlovsky's scientific carecr was devoted mainly to investigations on venomous animals, for the study of which he devised refined methods of manual dissection, described in a series of handbooks and recently in Methoden der Sektion von Insekten (Berlin, 1960). The results of some of this work were incorporated in his M.Sc. thesis of the University of Petrograd, and eventually in an important monograph on venomous animals published in Germany (1927).

In the meantime, on the death of Cholodkovsky in 1921, Pavlovsky succeeded him as professor of biology and parasitology (as the chair was renamed). During this period, the upheaval caused by the First World War and then by the eivil war brought about an aftermath of pandemic outbreaks of malaria, typhus and other infectious diseases which were ravaging the young Soviet Republic. Pavlovsky responded to the urgent necessity of dealing with the disastrous situation by directing all his energy and knowledge to problems of public health, thereby initiating the second, and most fruitful, period of his scientific activities, to which he dedicated the rest of his life. From 1928 onwards Pavlovsky and his teams carried out more than 160 parasitological and epidemiological surveys throughout the U.S.S.R. These expeditions revealed a close connexion between diverse arthropod-borne infections of man and lower mammals, which were shown to be zoonoses (for example, seasonal encephalitides, relapsing fevers, leishmaniases), and laid the foundation, in 1939, of the concept of natural foci (or focality) of transmissible diseases, which was Pavlovsky's most outstanding achievement.

Ho demonstrated that some of these diseases are naturally localized in foci within well-defined geographical areas (biotopes), where the pathogenic organisms, their vectors and hosts form an ecological association (biocenose) within which the infection eirculates for indefinite periods of time from donor-hosts via vectors to recipient-hostsrepresented by wild animals-quite independently of man. It is only when human beings intrude on such an enzootic locality or settle down to live there that they expose themselves to the attacks of the vectors, which then transmit to them the parasites acquired from the wild reservoir hosts. On the basis of this discovery, Pavlovsky formulated his idea of "landscape epidemiology": since natural enzootic foci are characterized by definite geographical peculiarities of the terrain, these can serve as indicators of the presence in a given area of certain diseases presenting a potential danger to man. The examination of the geographical background of zoonoses enabled Pavlovsky and his associates to detect and control numerous foci of human infections within the Soviet Union. It has also inspired a great volume of epidemiological investigations throughout the rest of the world. The recognition of its importance is reflected in the creation of centres for the study of zoonoses in South America, the United States and East Africa, as well as at the World Health Organization. 
To Pavlovsky also belongs the credit of developing an ecological approach to the phenomenon of parasitism, based on the recognition of the organism of the host as the environment of its parasites. He introduced the original concept of parasitocenoses, concerning the mutual relations between the components of the parasitic fauna of a host. One of the great merits of his scientific activities was the application of scientific principles to the solution of problems of practical importance in public health, which resulted in the local eradication of certain diseases. Pavlovsky was the author of more than 1,000 publications, devoted to parasitology, entomology, microbiology, epidemiology, toxicology and evolution, as well as to the history of biology and medicine, and including several monographs and text-books. Some of his most important works have recently been brought together in three volumes (in Russian): General Principles of Parasitology and Zoology (1961); Collected Papers on Experimental Zoology and Toxic Animals (1963); and Collected Papers on Experimental Parasitology (1963), as well as in the following English versions: Human Diseases with Natural
Foci (Moscow, 1963) and Natural Nidality of Transmissible Diseases, with special reference to the Landscape Epidemiology of Zooanthroponoses (in the press: U.S.A.). Pavlovsky was also an outstanding teacher, who created an imposing school of Russian parasitologists.

In addition to the professorship at the Military Medical Academy, which he relinquished in 1958 with the rank of Lieutenant-General in the Soviet Army Medical Service, Pavlovsky was for many years director of the Zoological Institute of the Academy of Sciences and president of the Geographical and Entomological Societies of the U.S.S.R. He was also an honorary member of several academies of science and of numerous learned societies outside his own country. For his outstanding scientific achievements he was elected a member of the Academy of Sciences in 1939 and of the Academy of Medical Sciences of the U.S.S.R. in 1944; he was awarded the honorary degree of 1D.-ès-Se. of the Sorbonne, and was the recipient of many prizes and medals, including the Darwin-Wallace Medal of the Linnean Society in 1959 .
Cectl A. HoAre

\section{NEWS and VIEWS}

\section{Civil Engineering in the Welsh College of Advanced Technology, Cardiff: \\ Prof. J. D. Geddes}

DR. J. D. GEDDEs, senior lecturer in civil engineering materials in the University of Newcastle upon Tyne, has been appointed professor of civil engineering in the Welsh College of Advanced Technology, Cardiff, from January 1. Dr. Geddes gained a first-class honours degree at the University of Newcastle upon Tyne in 1949. Later, after work with consulting civil engineers, he returned to his alma mater to work on the subject of piled foundations; he was awarded a Ph.D. for this work at the age of twenty-five. His research was carried out under the Radley postgraduate studentship of the Institute of Civil Engineers, of which body Dr. Geddes already held the distinction of a Miller Prize. In later years he was to be awarded prizes and a Bronze Medal by the Institution of Structural Engineers for his work on mining subsidence. After a year or two as head of the Federal Laboratory of the Public Works Department of Nigeria, controlling all testing and site investigation, he again returned to the University of Newcastle upon Tyne and, for the past 10 years, has been head of the Materials and Building Science Division of the Department of Civil Engineering in the University. His researches have covered mining subsidence and its effects, heat flow through concrete, stresses in buried pipelines, the part played by grout in pre-stressed concrete construction, and studies in site investigation. Dr. Geddes has controlled an effective testing laboratory run by the Department as a regional service, and has forged a bond between the profession and the University. He has found time to become an authority on the history of the British regiments and will return in the spring to give a University lecture on the subject in Newcastle. His new students will also welcome his contributions to Problems in Engineering Soils - a text-book soon to be published under joint authorship.

\section{Fast Reactor Agreement}

The United Kingdom Atomic Energy Authority and Aktiebolaget Atomenergi, Sweden, have concluded an agreement for exchange of information and collaboration on fast reactor research and development. Information to be exchanged concerns design and operating experience from research and experimental reactors, basic physical and chemical properties of materials for use in fast reactors and reactor physies, as well as operating experience with certain fuels. The agreement will be effected by means of reports and visits. There may be exchanges of staff from time to time. The progress of the agreement will be reviewed periodically at meetings between representatives of the Authority and Aktiebolaget Atomenergi.

\section{Ministry of Technology}

Is written answers in the House of Commons on November 30, the Minister of Technology, Mr. F. Cousins, listed sixteen projects on which he had required the Atomic Energy Authority to carry out research at estimated costs varying from $£ 500$ to $£ 73,000$ during the financial year 1964-65 and totalling more than $£ 377,800$. These projects involved 108 people full-time or part-time, and accounted for about 1 per cent of the Authority's effort on civil research and development in 1965 . In addition, work on some minor projects had been authorized, and certain preliminary investigations were being made, while Aldermaston was undertaking non-atomic work on repayment for Government departments, mainly in

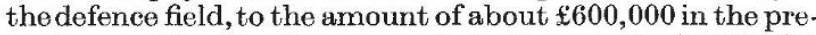
sent year. Desalination research, to the extent of $£ 278,000$, was proceeding at Winfrith, Culcheth, Harwell and Risley; work is also under way on hydrostatic extrusion ( $£ 54,000)$ at Springfields, on a medical centrifuge $(£ 15,000)$ at Capenhurst, and on a design study for scientific payload for the European Space Research Organization satellite $(£ 41,000)$ at Culham and Aldermaston. 'The Authority's expenditure on civil nuclear research and development is given as $£ 47.9$ million. Of the $£ 35$ million shown in the Authority's civil trading account as the proceeds of sales for the year ended March 31, 1965, 60 per cent is attributed to fuel elements for civil reactors, 20 per cont to electricity and 6 per cent to radioaetive isotopes. Of the $£ 6.5$ million expenditure on the Ministry of Technology in the past 12 months, $£ 4.5$ million was for research stations, just under $£ 2$ million on grants for research to research associations and other bodies, and $£ 650,000$ on the Ministry's headquarters. Appropriations in aid amounted to $£ 850,000$.

\section{Mechanical and Electrical Engineering}

IN a written answer in the House of Commons on December 1, the Prime Minister, Mr. H. Wilson, stated that the Ministry of Technology would now assume responsibility for sponsoring the mechanical and electrical 